\title{
Study on the Orientation, Path and Measure of Computer Course Teaching in Higher Vocational Education
}

\author{
Fang Wang \\ Liaoning Jianzhu Vocational College, Shenyang, Liaoning, 111000
}

Keywords: Higher Vocational Education, Computer Course Teaching, Path and Measures

\begin{abstract}
In order to successfully complete the teaching task and promote the improvement of teaching quality, it is necessary to correctly set the teaching goal, pay attention to the basic knowledge, teach computer application skills and encourage students to innovate. And how to improve teaching facilities, improve the quality of teachers, stimulate learning motivation are important issues to be addressed. Scientific and effective methods shall be used to strengthen the teaching of basic knowledge, professional skills training, innovative ability of students, and innovative teaching methods. This method will not only innovate teaching methods, effectively guide the teaching, but also ensure the effectiveness of computer teaching and personnel training quality.
\end{abstract}

\section{Introduction}

With the accelerated development of information and network technologies, computers have become an indispensable basic tool in the work, study and life of modern society. Proficiency in computer basic application of technology, should become the basic requirements of vocational graduates. Subject to the influence of many factors such as teachers' ability, hardware investment and attitude towards learning, as a vocational school that aims at cultivating a practical teaching ability, the higher vocational schools have listed computer courses as public compulsory courses, but in fact they do not know well and value Not enough, or even mere formality, hope the students "selfless" or "self-taught" [1]. Compared with the rapid development of computer technology, some higher vocational colleges lack of improvement in the level of computer teaching and quality, teaching content "old age", the teacher "do not have to teach", students "do not need to learn", teachers and students related knowledge and skills gap Getting smaller and smaller, and even "win each other." We must follow the requirements of the development of the situation and apply the latest technological achievements to guide vocational students to master and work skillfully while mastering computers and networks. They should be able to engage in higher vocational teaching of computer Serious thinking of the problem and the pursuit of the goal. In this paper, in recent years engaged in teaching of higher vocational courses in some practice and experience, make some sorts of this, put forward some suggestions for the exchange.

\section{Higher Vocational Computer Course Teaching Positioning}

Reasonable course positioning, which is the first problem to be solved in vocational computer teaching, teaching activities can be targeted, oriented. Under the clear goal guidance, teachers can effectively explain the knowledge, students can enhance the understanding of teaching content, the knowledge learned into their own professional skills. Vocational computer includes a wealth of course teaching content, and structured, master this knowledge for future learning and work has a positive effect. As the goal of higher vocational education is to train more applied talents for the whole society, students should learn more about theoretical knowledge, cybersecurity, procedural languages and comprehend basic principles and knowledge on the one hand. At the same time also need to master common computer technology knowledge, including spreadsheets, LAN technology, database technology, to guide the practical operation, rich professional knowledge and practical skills. In the age of information and internet, people's life and learning are inseparable from the 
computer. Therefore, the emphasis should be placed on the teaching of applied skills in computer teaching in higher vocational education, and the students should be trained as skilled talents. The use of project teaching method, case teaching method, so that students a clear teaching tasks, in-depth exploration, learning and master this knowledge and improve practical skills. The application of computer expertise and comprehensive technology is also the process of solving specific problems. We should pay attention to cultivating the students' innovative spirit as the goal and orientation of the course teaching. Training students to explore awareness, with questions to think and explore, in-depth understanding of computer-related concepts, effective control of the corresponding computer technology operation process [2].

With the popularization of computers, students in higher vocational colleges should not only enhance the basic knowledge of the theory, but also emphasize the practice of skills training, highlighting the ability of application in teaching so that students can effectively integrate them into classroom learning activities. This requires measures to be taken in teaching facilities, teaching staff building and students' learning motivation to be more effectively integrated into learning activities.

\section{Higher Vocational Computer Courses Need to Focus on Strengthening the Content}

Many professional computer applications have been very deep and wide, leaving the computer application almost impossible to carry out this professional work, such as accounting, design and so on. In the hardware is generally no particular circumstances, the application of industry software has become the core. It is very important and necessary to effectively teach basic knowledge of computers, networks and databases to professional students with professional software applications as the center. As a computer course teacher, in the case of professional computer content can not be a book, we must own more and more hardworking, from the vocational work in the future of computer applications in the future, intentions to prepare the professional computer basic content tutorial, the students should have Basic knowledge, basic principles, basic operations, real teaching instructions, so that students really need to be pragmatic. Such basic work, need teachers intentions, students work hard, assessment hard. Can not know why they are, the results can not be skilled to know, to guide students to master this basic truth, make efforts to master those who need to master the basic knowledge and skills [3].

The same is true of computer applications, will not be representative of proficient, never used to represent skilled. Only diligently practice, in order to continue to have new gains. The emphasis of computer teaching lies in practical operation, and in the higher vocational colleges, the key lies in cultivating students' practical ability. As a computer course in higher vocational colleges, on the basis of imparting and mastering basic knowledge, we must guide students to devote more energy to the diligence and hard training of computer skills related to the profession, and only on the basis of continuous practice Practice makes perfect, in order to make the computer operation level become another important capital in the future employment of higher vocational students, rather than another short-term. Teachers in the teaching process should give students enough time to operate the machine, we should make full use of resources within the school to strengthen the experimental teaching, increase the machine test, improve students' proficiency in computer operations and the ability to solve practical problems [4].

Computer technology is different from television used to entertainment, mobile phones used to communicate, it is mainly used to solve the problem. To solve the problem to rely more on innovation, can not be separated from the user's ability to innovate. Therefore, the study of computer courses in higher vocational colleges should become the process of innovation learning and cultivation. It is necessary to change the single computer teaching mode, create innovative and harmonious classrooms for students, and guide students to better solve the problems through computer learning, Get higher efficiency. Interest is the best and most useful teacher, but also the source of innovation is the most likely source. We should pay attention to cultivate students' interest and let students enhance their innovative ability under the guidance of strong interest. When designing computer operation, students are required to use their own characteristics, not to have the same pattern and the same sentence, to regard each computer operation as Write your own writing 
process.

\section{Effective methods in higher vocational computer courses}

At present, the application of computer is very extensive. The teaching should fully understand its purpose, pay attention to the teaching of basic knowledge, pass the basic knowledge of basic theory, network technology, system maintenance, database and other basic knowledge to the students so that students can master these operations and deepen their understanding and understanding, it can be effectively applied to classroom teaching activities and practice of specific operations. Pay attention to the compilation of teaching materials, improve the content of the curriculum, the basic principles of computers, basic operations and other content into the teaching materials, combined with the status of computer technology development and innovation, supplement and update the curriculum content, improve the content of the times, keeping up with the pace of the times, let students master the latest technology operation process, enhance the level of theoretical knowledge. Mastering computer professional skills is an important goal of teaching, but also lay the foundation for flexible application of computers to solve specific problems in the future. The key to higher vocational computer teaching is to cultivate students' hands-on skills. This is a content that needs to be carefully grasped in teaching and should be taken as a guideline and effectively implemented into the teaching activities of the course. Guide students to spend more energy on computer skills and practical training, through continuous operation, master the application skills, improve the level of computer expertise [5]. At the same time, students should also be given enough time to operate the computer. They should make effective use of the teaching resources in the school and carry out computer experiment teaching rationally and reasonably so as to enable students to master computer skills. Realizing teaching innovation and enhancing students' innovative skills are important tasks in higher vocational computer teaching. Teachers should be good at grasping the opportunity, reasonably using teaching situations, the introduction of problems, cooperative exploration, extra-curricular learning, ignite the spark of student innovation, stimulate innovative thinking potential, good at capturing inspiration, based on existing professional knowledge, to promote computer teaching Innovation.

Play the main role of students in the classroom, improve classroom participation, innovative teaching methods. For example, applying a task-driven approach allows students to explore computer-related knowledge, explore solutions, work hard at teaching tasks and gradually transform them into their skills with clear tasks. By using such methods as hierarchical teaching and cooperative learning methods, it will inject impetus into class activities, change the boring and teaching form of teaching, stimulate the vitality of computer classrooms in higher vocational schools and enable students to carry out effective learning. Learning computer courses and mastering the basic computer skills are the basic requirements for vocational students, but it is hard for them to act consciously. They must have ways to mobilize their interests and make them want to learn, take the initiative and study hard, Curiosity-driven initiative to explore, in order to improve learning efficiency, access to better learning outcomes. As a computer teacher, we should be well-intentioned, attentive, find the different needs of class students, according to the student's interest, ability to accept the specific circumstances of different education, to the latest and most practical computer technology to teach vocational students, So as to make their future employment paths more open. To create a good atmosphere, to stimulate students interest in the study and discussion, to carry out some competitions, so that students get the joy of success [6]. To create effective problem situations, students should get out of the traditional deep-rooted passive learning and actively participate in the interaction. Pay attention to using more advanced technology to attract students, because computer teaching itself is a highly technical course, especially multimedia courseware, to be fully applied, so that students in this practical application of real knowledge, master the true skills. 


\section{Conclusions}

The quality of computer application is very important to the future employment and development of higher vocational students. As a manager and other teachers in colleges and universities, we must all understand this. Only when all of you work together to create the conditions, the computer skills of the higher vocational students will be real Improve. One of the most important thing is to strengthen the construction of high-quality basic computer teaching staff, speaker must have a wealth of teaching experience. In addition, scientific research and teacher training should be strengthened to bring rich teaching contents and advanced teaching concepts to the teaching practice of computers. On the basis of teachers in place, to grasp the hardware in place, only after a large number of machine operation can really master the basic skills of the computer. To make full use of network resources, network technology for computer teaching, so that students through the network to communicate with teachers.

\section{References}

[1] Sun Lili. The new era of higher vocational teaching and thinking of computer [J]. New Curriculum, 2014 (1): 154-155.

[2] Zheng Yin. Cultivating Students' Exploration Spirit in Higher Vocational Computer Teaching [J]. Modern Communication: Second Half, 2014 (2): 223-224.

[3] $\mathrm{Bi}$ Wei. Analysis of the status quo and countermeasures of computer teaching in higher vocational colleges [J]. Examination Weekly, 2014 (33): 45-46.

[4] Khalidhara. Computer Teaching Research Based on Interactive Teaching in Higher Vocational Education [J]. China Science Education Innovation Guide, 2014 (5): 161-164.

[5] Yang Shuzhen. Analysis of computer teaching reform in higher vocational colleges [J]. China Out-of-school education: late, 2014 (3): 167-168. 